The level of BPI before surgery in group 2 was significantly higher than that in group $1(10.5 \mathrm{ng} / \mathrm{ml}$ (3.35-19.05) and $3.33 \mathrm{ng} / \mathrm{ml}(2.74-4.51) \mathrm{p}<0.05$, respectively). In a group data comparison, BPI was significantly higher in group 1 , even on the third day after surgery $(2.915 \mathrm{ng} / \mathrm{ml}(1.37-55.5)$ and 15.75 $\mathrm{ng} / \mathrm{ml}(3.32-50.5) \mathrm{p}<0.05$, respectively). The data showed values of BPI in the group of patients with inflammatory complications that were higher than those in the main and comparison groups from the third postoperative day.

The increased BPI in the blood on the first postoperative day in newborns was a good prognostic sign. An initial low level BPI and the increased BPI in the blood on the third postoperative day in newborns was a poor prognostic sign and was evidence of development of inflammatory complications.

Key words: gastrointestinal tract, congenital anomaly, infants, bactericidal/permeability-increasing protein ветственно). При сравнении показателей ВРІ на третий день после операции отмечалось значительное $(p<0.05)$ его повышение в группе № $1(15,75$ ng/ml $(3,32-50,5))$ по сравнению с группой № $2(2,915 \mathrm{ng} / \mathrm{ml}(1,37-55,5))$. Установлено статистически достоверное $(p<0,05)$ увеличение уровня ВPI на 3-и сутки у пациентов с послеоперационными осложнениями.

Таким образом, высокий уровень ВPI у новорожденных с хирургической патологией ЖКТ в 1-е сутки благоприятный прогностический признак. Исходно низкий уровень ВРІ в сыворотке крови ребенка в сочетании с его нарастанием на 3-и сутки может служить маркером развития послеоперационных осложнений.

Ключевые слова: желудочно-кишечный тракт, врожденная аномалия, новорожденные, бактерицидный белок, повышающий проницаемость клеток

\title{
SLEEVE GASTRECTOMY FOR MORBID OBESITY - REGIONAL EXPERIENCE
}

\author{
Khatsiev B. B., Kuzminov A. N.
}

\section{Stavropol State Medical University, Russian Federation}

$\mathbf{M}$ orbid obesity is the actual issue for healthcare of developed countries. In Russia $51 \%$ of men and $58 \%$ of women are either overweight or obese[1]. Obesity is closely associated with type 2 diabetes mellitus, arterial hypertension and other diseases [2].

Meta-analysis of numerous randomized studies had shown that bariatric surgery can induce not only weight-loss, but also is more effective in management of type 2 diabetes mellitus than conservative treatment, including long-term period [3].

Sleeve gastrectomy is one of the most recent widely recognized bariatric procedures. While it is not completely clear whether it should be used as primary procedure, number of sleeve gastrectomies constantly increases [4]. In 2012 sleeve gastrectomy became the most common bariatric operation in Russia, shifting adjustable gastric banding to the second position [5].

Objective of research. This study summarizes result of three-year experience of sleeve gastrectomy at regional clinics of Stavropol kray. The results will contribute to the regional strategy of treatment

Khatsiev Bekhan, MD, PhD, deputy director of Clinic of endoscopic and minimally invasive surgery, Stavropol State Medical University; tel.: +79283211335; e-mail: bkhatsiev@yandex.ru

Kuzminov Alexander, MD, surgeon of Clinic of endoscopic and minimally invasive surgery, Stavropol State Medical University; tel.: +79283296633; e-mail: dr.kuzminov@gmail.com of morbid obesity and diabetes mellitus. This paper also aims to reveal information on bariatric surgery to regional surgeons, endocrinologists and general practitioners.

Material and Methods. We have been performing sleeve gastrectomies since December 2010. 116 operations have been made by the March 2014; 24 (21\%) patients are males, 92 (79\%) - females. Mean age of patients is $38.0 \pm 9.8$ years, minimal age -15 , maximal - 62. Average body mass index (BMI) is $46.5 \pm 7.3 \mathrm{~kg} / \mathrm{m}^{2}$, minimal BMl $-34.3 \mathrm{~kg} / \mathrm{m}^{2}$, maxi$\mathrm{mal}-72,7 \mathrm{~kg} / \mathrm{m}^{2}$. Maximal patient weight was $215 \mathrm{~kg}$.

Insulin resistance or glucose intolerance pre-operatively were find out in $16(13,8 \%)$ patients, $12(13,8 \%)$ patients suffered type 2 diabetes mellitus with oral therapy, $2(1.7 \%)$ more patients were on insulin treatment.

All procedures were carried put under general endotracheal anesthesia that was augmented in $12(10.3 \%)$ cases with peridural anesthesia. In $19 \%$ of cases other operations were performed simultaneously - 16 (13.8 \%) cholecystectomies, 4 (3.4\%) hernia repairs, $1(0.8 \%)$ ovarian cyst removal $n$ $1(0.8 \%)$ adhesiolysis.

2 operations were performed by laparotomy (due to multiple previous laparotomies), 1 operation commenced as laparoscopic, but was converted to hand-assisted with usage of minimally invasive system «Dextrus» due to enormous size of left hepatic 
lobe that significantly restricted manipulations in the operative zone. 113 operations (97,4\%) were carried out laparoscopically.

Average operative time was $110 \pm 51$ minutes (including prolonged first operations). The trend towards operative time decreasing can be seen at Fig. 1 .

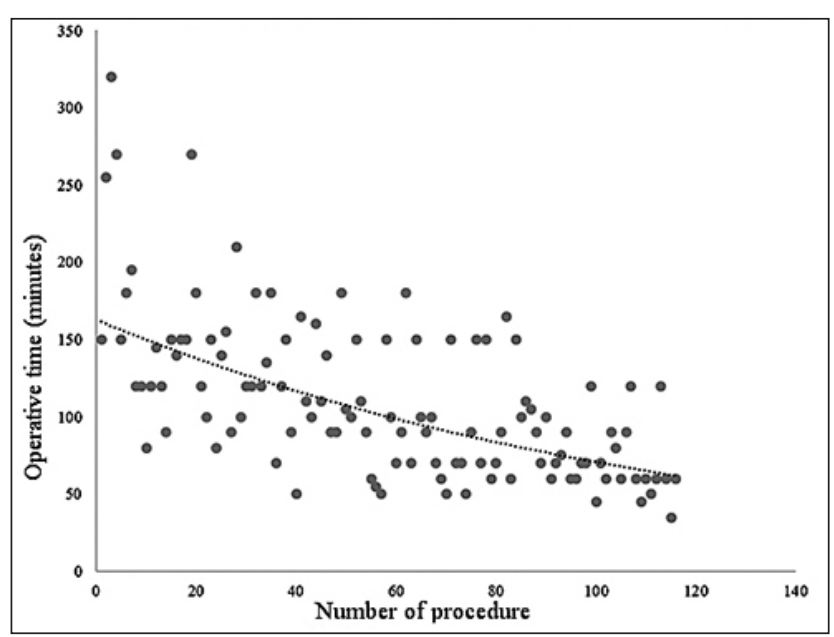

Fig. 1. Relation between operative time and operative experience

Results. Early postoperative complications developed in $8(6.9 \%)$ patients, directly caused by manipulation were $7(6.0 \%)$ complications. We used Clavien-Dindo staging of surgical complications system for analysis. I stage complications (those that do not require any special treatment) were in $2(1.7 \%)$ patients; II stage (conservative treatment) developed in 1 patient; IIIb (reoperation under general anesthesia) developed in $3(2.6 \%)$ patients; IVa stage (complication that requires treatment at ICU) were in $2(1.7 \%)$ patients. Details of complications are revealed in Table.

Post-operative complications after sleeve Table gastrectomy

\begin{tabular}{|l|c|c|c|}
\hline Complication & Number & Rate (\%) & Stage (Clavien-Dindo) \\
\hline $\begin{array}{l}\text { Phlebitis } \\
\text { at PVC zone }\end{array}$ & 1 & 0.8 & I stage \\
\hline $\begin{array}{l}\text { Abdominal } \\
\text { bleeding }\end{array}$ & 5 & 4.3 & $\begin{array}{c}\text { I stage }-1 \\
\text { II stage }-1 \\
\text { IIIb stage - } \\
\text { IVa stage - 2 }\end{array}$ \\
\hline $\begin{array}{l}\text { Staple line } \\
\text { leakage }\end{array}$ & 2 & 1.7 & IIIb stage - 2 \\
\hline
\end{tabular}

Both patients with staple line leakages were reoperated (laparoscopic sewing of the leakage site and drainage tube placement). Sewing of distal leak site was completely effective, while operation in patient with proximal leakage did not completely

\section{References}

1. Rtveladze K., Marsh T., Webber L., Kilpi F., Goryakin Y., Kontsevaya A., Starodubova A., Mcpherson K., Brown M. Obesity trends in Russia. The impact on health and healthcare costs. Health. 2012;4:1471-1484.

2. Picot J., Jones J., Colquitt J.L., Gospodarevskaya E., Loveman E., Baxter L., Clegg A.J. The clinical closed the leakage; however, this zone was effectively drained with formation of gastric fistula that spontaneously healed 2 months after.

Analysis of weight loss showed that during first three months after operation average excessive weight loss (\% EWL) was $36.0 \pm 11.0 \%$, after 6 months it was $50.1 \pm 15.5 \%, 9$ months post-op excessive weight decreased by $54.0 \pm 12.0 \%$, and one year after it dropped by $57.3 \pm 14.0 \%$. After the first year slight weight regain was noticed: 18 months

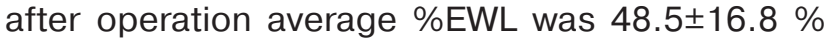
with further stabilization at the level of $483 \pm 15.2 \%$ 2 years (22 - 30 months) after operation. Moreover, looking at quartiles it can be seen that $75 \%$ of patients stabilize their weight 9 months after the primary procedure. This is shown at Fig. 2.

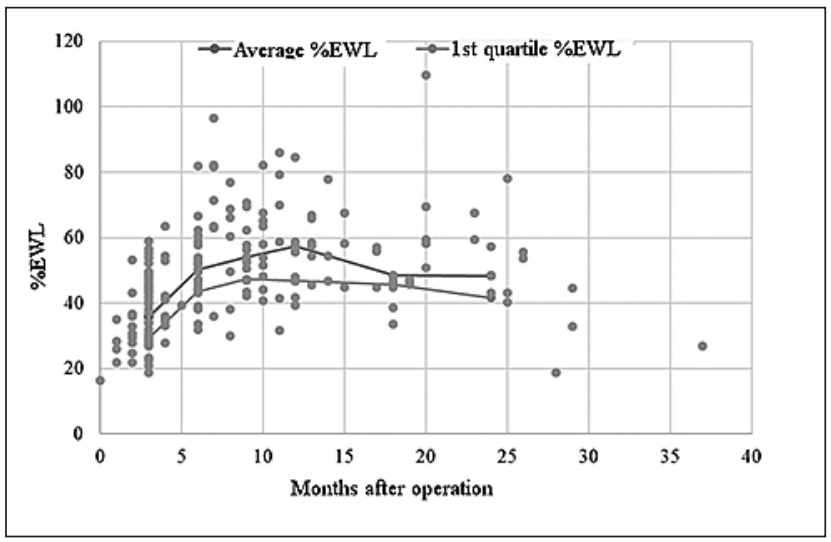

Fig. 2. Excessive weight loss (\% EWL) after sleeve gastrectomy

During the first three months after the operation 13 patients with type 2 diabetes mellitus stopped conservative treatment due to normal glucose level. 1 patient with diabetes dropped-out from the follow-up program. In two patients time after operation is not sufficient to make any conclusions yet (less than 1 month has passed since operation date to follow-up).

Conclusion. Sleeve gastrectomy has demonstrated good results in treatment of both morbid obesity and type 2 diabetes. During follow-ups patients express their content with increasing quality of life. Influence of sleeve gastrectomy on fertility is not studied so far. We were informed on 5 pregnancies after our operations in previously infertile patients who were unsuccessfully treated conservatively.

Further follow-ups should be recorded to evaluate long-term results of sleeve gastrectomy in weight control. However, the current date available convinces us that this procedure should be used as primary in morbid obesity and co-morbid type 2 diabetes. effectiveness and cost-effectiveness of bariatric (weight loss) surgery for obesity: a systematic review and economic evaluation. Health technology assessment. 2009;13(41):1-190, 215-357, iii-iv.

3. Gloy V. L., Briel M., Bhatt D. L., Kashyap S. R., Schauer P. R., Mingrone G., Bucher H. C., Nordmann A. J. Bariatric surgery versus non-surgical treatment for obesity: a 
systematic review and meta-analysis of randomised controlled trials. Bmj. 2013;347f5934.

4. Fischer L., Hildebrandt C., Bruckner T., Kenngott H., Linke G. R., Gehrig T., Buchler M. W., MullerStich B. P. Excessive weight loss after sleeve

\section{SLEEVE GASTRECTOMY FOR MORBID OBESITY - REGIONAL EXPERIENCE \\ KHATSIEV B. B., KUZMINOV A. N.}

This paper summarizes experience of 116 sleeve gastrectomies performed in Stavropol for the last three years. Average operative time was $110 \pm 51$ minutes. Complication rate was $6.9 \%$ with no mortality. 5 (4.3\%) patients were reoperated due to complications. Staple line leakage rate was $1.7 \%$.

Average excessive weight loss in 12 months after the surgery egualled operation was $57.3 \%$ with a regain up to $48.3 \%$ two years after the primary procedure. Sleeve gastrectomy demonstrated high efficacy in treatment of $2^{\text {nd }}$ type diabetes mellitus resolving it in all followed up patients. 5 pregnancies in previously infertile patients were reported.

Therefore, this operation may be recommended as standalone primary bariatric procedure.

Key words: bariatric surgery, sleeve gastrectomy, obesity gastrectomy: a systematic review. Obes Surg 2012;22(5):721-731

5. Yashkov Y., Khatsiev B., Kuzminov A. Data of the Russian National Bariatric Registry in 2012. Obesity Surgery. 2013;23(8):1076.

\section{ПРОАОАЬНАЯ РЕЗЕКЦИЯ ЖЕАУАКА \\ ПРИ МОРБИАНОМ ОЖИРЕНИИ - РЕГИОНААЬНЫЙ ОПЫТ}

Б. Б. ХАЦИЕВ, А. Н. КУЗЬМИНОВ

В статье суммируется опыт 116 продольных резекций желудка, выполненных в Ставрополе за последние 3 года. Среднее время операции составило $110 \pm 51$ минут. Частота осложнений составила 6,9 \% с нулевой летальностью. 5 (4,3 \%) пациентов были повторно оперированы в связи с осложнениями. Частота несостоятельности степлерной линии в анализируемой группе составила 1,7\%.

Среднее снижение избыточного веса через 12 месяцев после операции равнялось 57,3 \% с незначительным повторным набором - через два года после операции снижение избыточного веса было на уровне 48,3 \%. Продольная резекция желудка продемонстрировала высокую эффективность при сахарном диабете 2 типа у всех пациентов анализируемой группы. Кроме того, в послеоперационном периоде отмечена беременность у 5 пациенток, ранее лечившихся по поводу бесплодия.

Таким образом, наш опыт позволяет рекомендовать продольную резекцию желудка как первичную самостоятельную бариатрическую операцию.

Ключевые слова: бариатрическая хирургия, продольная резекция желудка, ожирение

\title{
APARASITISM AND ANTI-PARASITISM PRINCIPLE IN LIVER ECHINOCOCCOSIS SURGERY: RESULTS
}

\author{
Vafin A. Z., Aidemirov A. N., Abdokov A. D., Popov A. V., Mashurova E. V., Malanka M. I.
}

\section{Stavropol State Medical University, Russian Federation}

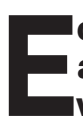
chinococcosis remains a severe disease affecting both animals and humans, which is associated with a longer course,

Vafin Albert, MD, PhD, Professor, Department of Hospital Surgery, Stavropol State Medical University;

tel.: (8652)717003; e-mail: azvafin@mail.ru

Aidemirov Artur, MD, PhD, Head of Department

of Hospital Surgery, Stavropol State Medical University;

tel.: 8(8652)479697; e-mail: aaidemirov@mail.ru

Abdokov Artur, MD, Assistant, Department of Hospital Surgery, Stavropol State Medical University;

tel. : 89283097050

Popov Alexander, MD; Deputy Chief, State Budgetary Healthcare Institution of Stavropol Region Stavropol regional clinical hospital tel.: 89054969703

Mashurova Ekaterina, MD; Assistant, Department of Hospital Surgery, Stavropol State Medical University; tel.: 89283395095 progressively aggravating condition and, if no treatment taken in due time, with a fatal outcome at an early age. Echinococcosis is spread in various countries of South Europe, Asia, and South America. In Russia, the endemic areas include the North Caucasus and the Stavropol Region namely as part of that. Echinococcosis may develop in any organs and tissues of the intermediate host while affecting the liver most often $[2,8,9]$.

In order to improve the surgical treatment of echinococcosis, our clinic (1980-1983) developed and introduced the general principles of aparasitism and anti-parasitism [4] to be further perfected, expanded, and implemented in clinical practices stage by stage $[5,6,7]$. 